\title{
Toxicity Issues Associated with Geogenic Arsenic in the Groundwater-Soil-Plant-Human Continuum
}

\author{
A. L. Juhasz, ${ }^{1, \star}$ R. Naidu, ${ }^{1, \star}$ Y. G. Zhu, ${ }^{2}$ L. S. Wang, ${ }^{3}$ J. Y. Jiang, ${ }^{3}$ Z. H. $\mathrm{Cao}^{4}$ \\ 1 CSIRO Land and Water, Private Mail Bag 2, Glen Osmond, Adelaide, S.A., 5064, \\ Australia \\ 2 Research Centre for Eco-environmental Sciences, Chinese Academy of Sciences, \\ Beijing, 100085, People's Republic of China \\ 3 Xinjiang Research Institute of Endemic Disease Control, Urumuchi, Xinjiang, \\ 830002, People's Republic of China \\ 4 Institute of Soil Science, Chinese Academy of Sciences, Nanjing, 210008, People's \\ Republic of China
}

Received: 31 August 2002/Accepted: 30 August 2003

During the past 20 years, increasing incidences have been reported where the concentrations of constituents associated with the natural mineralization of soils and substrata are at levels that may cause adverse effects on ecosystem and human health (Bhattacharya et al. 1997). Such pollutants are defined as geogenic contaminants and may include arsenic, selenium, fluoride and radionuclides. Adverse impacts of geogenic contaminants on ecosystem and human health have been recorded in many countries worldwide including Argentina, China, USA, Canada, Bangladesh, West Bengal and India (Bhattacharya et al. 2002). The focus of this paper is on the source, release and transfer of arsenic (As), from native mineral species, to plants and humans via water and soil with particular reference to incidences of health effects recorded in the South East Asia region.

Arsenic is the $20^{\text {th }}$ most abundant element in the earth's crust (av. $2 \mathrm{mg} \mathrm{kg}^{-1}$ ) (NAS 1977) and is present in more than 200 minerals. It forms arsenide minerals with copper, lead, silver and gold and is commonly associated with sulfides such as pyrite $\left(\mathrm{FeS}_{2}\right)$ and arsenopyrite $(\mathrm{FeAsS})$. Arsenic may occur in a reduced form as orpiment $\left(\mathrm{As}_{2} \mathrm{Ss}\right)$ and realgar $(\mathrm{AsS})$ or with oxygen as arsenolite $\left(\mathrm{As}_{2} \mathrm{O}_{3}\right)$ or its polymorph, claudite. In addition, As is also associated with new secondary minerals in sediments as a result of weathering (Gaines et al. 1997). However, the mineral species at a given location is dependent on the physico-chemical conditions at the time of formation or mineralisation and the stability of that species.

Arsenic has two primary oxidation states under earth surface conditions. Arsenite $\left(A s^{\mathrm{III}}\right)$ is the dominant form of arsenic while arsenate $\left(\mathrm{As}^{\mathrm{V}}\right)$ is generally the stable form under oxygenated conditions. At neutral $\mathrm{pH}, \mathrm{As}^{\text {III }}$ strongly adsorbs onto iron oxides, clays and other soil components while $\mathrm{As}{ }^{\mathrm{V}}$ shows strong adsorption at lower $\mathrm{pH}$ values (4 to 7) (Smith et al. 1998). Although $\mathrm{As}^{\mathrm{V}}$ binds specifically to iron and manganese oxyhydroxides under acidic conditions, dissolution of the mineral phase at $\mathrm{pH}$ values $<4$ would lead to enhanced release of $\mathrm{As}^{\mathrm{V}}$. Redox potential also influences the release of As from iron and manganese oxyhydroxides. Under reducing conditions there may be enhanced release of As

\footnotetext{
*Present address: Centre for Environmental Risk Assessment and Remediation, University of South Australia, Mawson Lakes, S.A., 5095, Australia Correspondence to: R. Naidu
} 
due to the decreased stability of the mineral phases. In addition, $\mathrm{As}^{\mathrm{V}}$ can be readily desorbed with an increase in $\mathrm{pH}$ or in the presence of competing anions such as $\mathrm{PO}_{4}, \mathrm{MoO}_{4}, \mathrm{SO}_{4}$ and dissolved organic acids (Smith et al. 1998).

The chemical form and speciation of As influences its toxicity. Numerous animal-based studies have shown that inorganic As is more toxic than organic As and inorganic $\mathrm{As}^{\mathrm{III}}$ is more toxic than inorganic $\mathrm{As}^{\mathrm{V}}$ (NAS 1977). Arsenic may exert its toxic effect through the inactivation of enzyme systems such as those involved in cellular energy in the citric acid cycle (Gomez-Caminero et al. 2001). $\mathrm{As} \mathrm{As}^{\mathrm{V}}$ does not react directly with the active sites of enzymes, it is first reduced to As ${ }^{\text {III }}$ in vivo before exerting its toxic effect. Arsenic can also compete with phosphate during oxidative phosphorylation forming an arsenate ester of ADP (Gomez-Caminero et al. 2001). Short-term exposure to As may result in gastrointestinal symptoms, disturbances of cardiovascular and nervous system function, bone marrow depression, haemolysis and melanosis while long-term exposure can produce various cancers (skin, lungs, bladder and kidneys), skin disorders (hyperkeratosis and pigment changes), vascular disease and Diabetes mellitus (Mandal and Suzuki 2002).

Problems associated with As contamination of groundwater and its adverse effect on human health in South East Asia were periodically reported in Bangladesh, China and India, during the early 1970s to late 1980s. However, limited attention was paid to such reports by the respective governments until the mid 1990's when evidence of arsenism to humans was reportedly related to tube well water. Subsequent water surveys revealed As-contamination of ground water in many villages in China, Taiwan and the Indian subcontinent. In these villages, millions of people are directly dependent on tube well water for both potable purposes and for cultivation. Clearly, the many incidences of poisoning recorded in this region are related to ingestion of geogenic As associated with groundwater, although the pathways of ingestion are not clear. The focus of work by local and international scientists in this region and worldwide is on the treatment of contaminated groundwater, on the basis that consumption of contaminated groundwater is the major exposure pathway.

\section{RELEASE OF ARSENIC FROM GEOGENIC SOURCES}

Geogenic As is released into the environment due to the weathering of Ascontaining minerals such as pyrite $\left(\mathrm{FeS}_{2}\right)$ and arsenopyrite $(\mathrm{FeAsS})$ (Bhattacharya et al. 2002). After exposure to oxygen and water, pyrite is weather to form $\mathrm{As}^{\mathrm{V}}$, $\mathrm{Fe}^{\mathrm{III}}$ and $\mathrm{SO}_{4}$ (equations 1 and 2).

$4 \mathrm{FeAsS}_{(\mathrm{s})}+14 \mathrm{O}_{2(\mathrm{~g})}+16 \mathrm{H}_{2} \mathrm{O}_{(\mathrm{l})} \Leftrightarrow 4 \mathrm{SO}_{4}{ }^{2-}{ }_{(\mathrm{aq})}+4 \mathrm{AsO}_{4}{ }^{3-}{ }_{(\mathrm{aq})}+4 \mathrm{Fe}(\mathrm{OH})_{3}+20 \mathrm{H}^{-}{ }_{(\mathrm{aq})}$
$2 \mathrm{FeS}_{2(\mathrm{~s})}+7 \mathrm{H}_{2} \mathrm{O}_{(\mathrm{l})}+7.5 \mathrm{O}_{2(\mathrm{~g})} \Rightarrow 2 \mathrm{Fe}(\mathrm{OH})_{3}(\mathrm{~s})+8 \mathrm{H}++4 \mathrm{SO}_{4}^{-}{ }_{(\mathrm{aq})}$ 
During the oxidation of pyrite, released $\mathrm{Fe}^{\mathrm{II}}$ may be oxidized to $\mathrm{Fe}^{\mathrm{III}}$ via biotic or abiotic processes. Once oxidized, ferric hydroxides may precipitate and become an important sorptive phase controlling the retention and mobilization of As.

Two contrasting theories have been proposed to explain the mechanism of As release and mobilization in the sedimentary aquifers of the Bengal Delta Plain. The first theory involves the release of As after oxidation of As-rich pyrite or arsenopyrite following the lowering of the water table during groundwater pumping (Bhattacharya et al. 2002) while the second theory involves desorption or release of As during iron oxyhydroxide reductive dissolution in reducing aquifer environments (Bhattacharya et al. 1997; Nickson et al. 1998). While growing evidence suggests that geogenic As release in Bangladesh and West Bengal occurs due to oxygenation of aquifer environments (Welch et al. 1988; Bhattacharya et al. 2002) (see equations 1 and 2), dissolution reactions involving As-containing secondary minerals and salts may contribute to As release in other areas around the world.

Recent surveys of tube well water in Bangladesh have revealed the calamity of geogenic As contamination. In 1998, a study conducted by the British Geological Survey found that $35 \%$ of water sampled (2022 samples from 41 districts) had As concentrations exceeding $50 \mu \mathrm{g} \mathrm{L}^{-1}$ (Smedley and Kinniburgh 2002). In an area previously identified as having As-contaminated tube well water, 62\% of the 32,651 wells had As concentrations exceeding $100 \mu \mathrm{g} \mathrm{L}^{-1}$ (Quamruzzaman 1999). It has been estimated that between 30 and 35 million of the 125 million inhabitants of Bangladesh are at risk of drinking As-contaminated water (BGS and DPHE 2001).

\section{TRANSFER OF ARSENIC TO THE SOIL ENVIRONMENT}

In the Indian subcontinent, groundwater is used extensively for crop irrigation and as a result, As is transferred to the soil environment. While little information exists on the rate of As transfer to agricultural land, studies at CSIRO Land and Water show As concentrations in surface soils in long term areas of irrigation in Bangladesh can exceed the guidance value of $100 \mathrm{mg} \mathrm{kg}^{-1}$ for residential soils. Brandsetter et al. (2000), using simple calculations, determined an As input of 4.5 $\mathrm{kg} \mathrm{As} \mathrm{ha} \mathrm{y}^{-1} \mathrm{y}^{-1}$ from irrigation water containing $1,100 \mu \mathrm{g} \mathrm{As} \mathrm{L}^{-1}$. This would result in an increase in As concentration in the top $15 \mathrm{~cm}$ by $3.0 \mathrm{mg} \mathrm{kg}^{-1} \mathrm{y}^{-1}$, however, the type of land use (i.e. rice verses vegetable production) would influence the rate of irrigation and therefore As inputs.

\section{ARSENIC EXPOSURE PATHWAYS}

Geogenic As exposure may result from a number of different pathways (Figure 1). The major pathway for As exposure is from consumption of As-contaminated drinking water. Due to climatic conditions and intensive labour in Bangladesh, it is not uncommon for an adult male to consume in excess of $4.5 \mathrm{~L}$ of water per 
day. Even with a moderate level of As in tube well water $\left(50 \mu \mathrm{g} \mathrm{L}^{-1}\right)$, this would equate to an As dose of $225 \mu \mathrm{g}$ day $^{-1}$. The US EPA risk reference dose $\left(\mathrm{R}_{\mathrm{f}} \mathrm{D}\right)$ for chronic As oral exposure is $0.3 \mu \mathrm{g} \mathrm{As} \mathrm{kg}{ }^{-1}$ day $^{-1}$ based on a NOAEL of $0.8 \mu \mathrm{g}$ As $\mathrm{kg}^{-1} \mathrm{day}^{-1}$ and a LOAEL of $14 \mu \mathrm{g}$ As $\mathrm{kg}^{-1} \mathrm{day}^{-1}$ for keratosis and hyperpigmentation (US EPA 1995). A dose of $225 \mu \mathrm{g} \mathrm{As} \mathrm{day}{ }^{-1}$ for a $60 \mathrm{~kg}$ person would equate to $3.75 \mu \mathrm{g} \mathrm{As} \mathrm{kg}{ }^{-1}$ day $^{-1}$ which is an order of magnitude greater than the US EPA As $\mathrm{R}_{\mathrm{f}} \mathrm{D}$. Dermal absorption of As during wetland rice farming is another possible exposure pathway for As-contaminated water, however, to date, this exposure route has not been quantified.

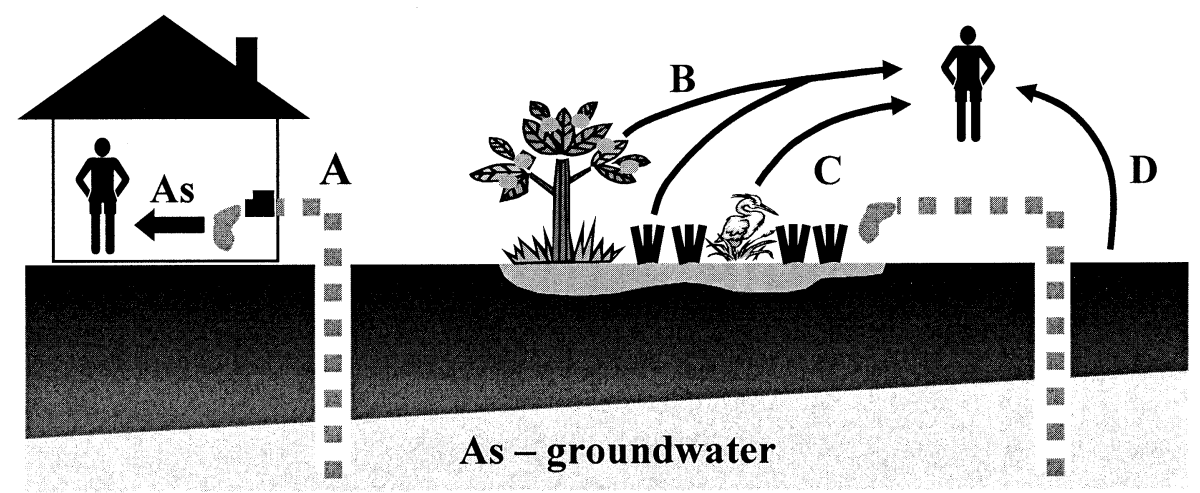

Figure 1. Arsenic exposure pathways; A: direct ingestion of As-contaminated drinking water; B: consumption of As-containing crops; C: consumption of Ascontaining animal products; D: incidental ingestion of As-contaminated soil.

Consumption of crops or animals raised on either As-contaminated soil or with As-contaminated groundwater is another potential pathway for As exposure. Numerous studies have shown that As can accumulate in vegetables, fruits, cereals and animal products (Table 1), however, little work has been performed to determine whether As is bioaccessible once these products are consumed. The accumulation of As in plants may vary quite considerably (from region to region and from site to site) depending on the plant's mode of As uptake and the concentration of As in the soil that is available to the plant (bioavailable fraction). In Bangladesh, the daily intake of vegetable products may be as high as $1 \mathrm{~kg}$ per person day $^{-1}$ (for 3 meals). Assuming an As vegetable content of $0.1 \mathrm{mg} \mathrm{kg}^{-1}$, the daily intake of As through this exposure pathway may be up to $100 \mu \mathrm{g} \mathrm{As} \mathrm{day}{ }^{-1}$.

Incidental ingestion of As-contaminated soil represents the principal exposure pathway for non-dietary intake of As (Basta et al. 2001). Studies have illustrated the importance of incidental soil ingestion as an important pathway for contaminant exposure in children (Davis et al. 1990). It has been estimated that children may consume up to $200 \mathrm{mg}$ of soil per day and the $<250 \mu \mathrm{m}$ soil fraction 
is the most likely to stick to hands and be ingested by the child. In addition, inadequate washing of vegetable material may also lead to a greater level of soil ingestion. Depending on the soil burden and the bioavailability of soil bound As, incidental ingestion of contaminated soil may be a significant pathway for As exposure.

Table 1. Arsenic concentrations in plant and animal material (Adapted from NAS 1977).

\begin{tabular}{lclc}
\hline Plant Material & $\begin{array}{c}\text { [As] } \mathrm{mg} \mathrm{kg}^{-1} \\
\text { dry weight }\end{array}$ & $\begin{array}{l}\text { Animal } \\
\text { Material }\end{array}$ & $\begin{array}{c}\text { [As] } \mathrm{mg} \mathrm{kg}^{-1} \\
\text { fresh weight }\end{array}$ \\
\hline Tomato & 0.3 & Pork & $0.3-0.9$ \\
Green pepper & 0.6 & Chicken & $0.2-1.2$ \\
Carrot & 1.2 & Rabbit & $1.0-2.0$ \\
Lettuce & 11.0 & Shrimp & $1.3-41.6$ \\
Celery & 5.5 & Crab & $18.8-62.6$ \\
Bean & 0.7 & Prawn & $27.0-130.5$ \\
Mango & 1.6 & Honey & $16.0-22.0$ \\
Apple & $0.04-1.7$ & & \\
Mandarin & 0.85 & & \\
Wheat & 14.6 & & \\
Barley & 4.0 & & \\
Rice & $0.5-5.0$ & & \\
\hline
\end{tabular}

\section{ARSENIC BIOAVAILABLITY}

A key parameter that influences As uptake and transfer up the food chain is bioavailability. Bioavailability refers to the ability of a chemical in the environment to interact with ecological receptors. In the case of geogenic As, bioavailability will influence the uptake of As by plants from soil, accessibility of soil borne As during incidental ingestion by animals and humans and accessibility of plant/animal associated As when consumed by animals and humans. Arsenic bioavailability is influence by a number of parameters including mineral form, particle size, encapsulating medium, soil properties, competing anions, environmental conditions, soil residence time and the physiology of the receptor organism (Juhasz et al. 2002).

Although a large number of plants have been shown to accumulate As (Meharg and Hartley-Whitaker 2002), uptake is dependent on the As available pool and its toxicological impacts on the plant. Studies have shown that soil parameters including anion exchange capacity, total organic carbon, clay content, clay type and mineral content (Fe, Al, Mn oxides) influence As in soil solution and the potential pool available for plant uptake. In addition, because of the interaction between phosphate and arsenate transport, As uptake is influenced by the concentration of available phosphate (Meharg and Hartley-Whitaker 2002). 
Little is known about the bioaccessibility of As ingested via contaminated plant and animal material. Arsenic may be present in various forms (e.g. $\mathrm{As}^{\mathrm{III}}, \mathrm{As}^{\mathrm{V}}$, monomethylarsonic acid, dimethylarsinic acid, trimethylasine oxide, arsenocholine, arsenobetaine, arsenosugar, arsenolipids) (Meharg and HartleyWhitaker 2002), which may influence its uptake. Although Table 1 shows As concentrations in plant and animal material, it is unknown what proportion of As is bioaccessible after consumption and therefore the risk posed by this exposure pathway. Determining the significance of this As exposure pathway is a future research challenge.

Recent studies have shown the bioavailability of As in contaminated soils, and therefore the amount that is potentially accessible for human or animal uptake (via incidental ingestion), is significantly less than 100\%. Casteel et al. (1997) assessed the bioavailability of As in 14 soil and mining waste materials using in vivo pig feeding trials and in vitro chemical methods. Arsenic bioavailability varied from near zero to $52 \%$ depending on the form of As present in the sample. Similarly, Juhasz et al. (2002) found the bioaccessibility of As in 18 contaminated soils (ranging from $22-1345 \mathrm{mg} \mathrm{As} \mathrm{kg}^{-1}$ ) to be less than $48 \%$. When quantifying the potential exposure from contaminated soils (i.e. the chemical daily intake), current regulatory guidelines assume $100 \%$ of the soil-borne contaminant is bioavailable. This assumption may result in the overestimation of exposure as demonstrated by the results of the above mentioned authors. The need to evaluate bioavailability arises from the fact that As species vary in their solubility and capacity to sorb to soil constituents, which will influence their uptake by receptor organisms. As a result, the assumption that the relative bioavailability of As is 1.0 may grossly overestimate exposure thereby influencing risk assessment and remediation decisions.

\section{MINIMIZING ARSENIC EXPOSURE}

As the main route for As exposure is via ingestion of contaminated drinking water, the majority of research has focussed on technologies for the removal of As from water or for alternative options for potable water. Most treatment technologies are based on reactions involving $\mathrm{As}^{\mathrm{V}}$ and an oxidic mineral or ion exchange surface (e.g. Fe oxides, alum, lime, activated alumina, resins, clays) (Montgomery 1985). Initially, an oxidation step is required to transform $\mathrm{As}^{\mathrm{III}}$ to $\mathrm{As}^{\mathrm{V}}$, which is achieved using oxidants such as chlorine, permanganate, solar radiation, oxygen or microbial processes (Montgomery, 1985; Korte and Fernando 1991). Arsenate is then either absorbed onto reactive surfaces or precipitated by mineral ions. While many of these treatments are currently used in developed countries (e.g. ion exchange, reverse osmosis, coagulation), the poor economy and infrastructure of developing countries, such as Bangladesh, have limited their application.

Treatment technologies for As-contaminated soil fall into two categories, (i) containment and (ii) removal. Containment of As-contaminated soil in situ may 
involve the use of phytostabilization, physical barriers or immobilization by $\mathrm{Fe}$ oxyhydroxides, $\mathrm{Mn}$ oxides or $\mathrm{FeSO}_{4}$ addition. Solidification-stabilisation techniques using polymer encapsulation or vitrification may be used to contain As-contaminated soil ex situ. Techniques used for the removal of As from soil include soil washing, microbial leaching (ex situ), soil flushing, electrokinetics, phytoextraction and biotransformation (in situ) (Lombi et al. 2000). Although a number of treatment technologies are available for As-contaminated soil, the magnitude of As contamination and the cost of these technologies preclude their application in Bangladesh. In addition to water and soil remediation, techniques for minimising the uptake of As by crops need to be considered. At present, no such techniques are available. A great challenge for future As research is the development of treatment and management strategies that are affordable, costeffective and socially acceptable. In addition, further quantification of alternative exposure routes (i.e. contaminated food and soil) is needed to determine the risk associated with these pathways and appropriate strategies for their management.

\section{Acknowledgements}

We thank the organizers of the First International Conference on Pollution, EcoChemistry and Ecological Processes (26-31 August 2002, Shenyang, China) where this paper was presented.

\section{REFERENCES}

Basta NT, Rodriguez RR, Casteel SW (2001) Bioavailability and risk of arsenic exposure by the soil ingestion pathway. In: Frankenberger WT Jr (ed): Environmental Chemistry of Arsenic. Marcel Dekker, New York, p 117-139.

BGH, DPHE (2001) Arsenic contamination of groundwater in Bangladesh. In: Kinniburgh DG, Smedley PL (eds) British Geological Survey Technical report WC/00/19, Keyworth.

Bhattacharya P, Chatterjee D, Jacks G (1997) Occurrence of arsenic contaminated groundwater in alluvial aquifers from Delta Plains, Eastern India: Options for safe drinking water supply. Int Water Res Manage 13: 79-92.

Bhattacharya P, Jacks G, Frisbie SH, Smith E, Naidu R, Sarkar B (2002) Arsenic in the environment: A global perspective. In: Sarkar B (ed) Heavy Metals in the Environment, Marcel Dekker, p 147-215.

Brandsetter A, Lombi E, Wenzel, WW, Adriano DC (2002) Arsenic-contaminated soils: I. Risk assessment. In: Wise DL, Trantolo DJ, Cichon EJ, Inyang HI, Stottmeister U (eds) Remediation Engineering of Contaminated Soil, Marcel Dekker, New York, p 715-737.

Casteel SW, Brown LD, Dunsmore ME, Weis CP, Henningsen GM, Hoffman E, Brattin RE, Hammon TL (1997) Relative bioavailability of arsenic in mining wastes. Document Control No. 4500-88-AORH. U.S. Environmental Protection Agency, Region 8, Denver, CO.

Davis S, Waller P, Buschom R, Bailou J, White P (1990) Quantitative estimates of soil ingestion in normal children between the ages of 2 and 7 years: 
Population-based estimates using aluminium, silican and titanium as soil tracer elements. Arch Environ Health 45: 112-122.

Gaines R, Skinner HCW, Foord E, Mason B, Rosensweig A (1997) Dana's new mineralogy: the system of mineralogy of James Dwight Dana and Edward Salisbury Dana. Wiley, New York.

Gomez-Caminero A, Howe P, Hughes M, Kenyon E, Lewis DR, Moore M, Ng J, Aito A, Becking G (2001) Arsenic and arsenic compounds, Environmental Health Criteria Monograph 224, World Health Organization, Geneva.

Juhasz AL, Smith E, Naidu R (2002) Estimation of human bioavailability of arsenic in contaminated soil. In: Langley A (ed) Proceedings of the Fourth National Workshop on Site Contamination, Adelaide, Australia, 13-15 May 2002, Monograph Series No. 8.

Korte NE, Fernando Q (1991) A review of arsenic (III) in groundwater. Crit Rev Environ Cont 21:1-39.

Lombi E, Wenzel, WW, Adriano DC (2002) Arsenic-contaminated soils: II. Remedial action. In: Wise DL, Trantolo DJ, Cichon EJ, Inyang HI, Stottmeister U (eds) Remediation Engineering of Contaminated Soil, Marcel Dekker, New York, p 739-758.

Mandal BK, Suzuki KT (2002) Arsenic round the world: a review. Talanta 58: 201-235.

Meharg AA, Hartley-Whitaker J (2002) Arsenic uptake and metabolism in arsenic resistant and non-resistant plant species. New Phytol 154: 29-43.

Montgomery JM (1985) Water treatment principles and design. John Wiley \& Sons, New York.

NAS (1977) Arsenic: medical and biologic effects of environmental pollutants. National Academy of Sciences, Washington, D.C.

Nickson R, McArthur J, Burgess W, Ahmed KM, Ravenscroft P, Rahman M (1998) Arsenic poisoning of Bangladesh groundwater. Nature 395:338.

Quamruzzaman Q (1999) Rapid action program: emergency arsenic mitigation program in two hundred villages in Bangladesh. In: Chappell WR, Abernathy $\mathrm{CO}$, Calderon RL (eds) Arsenic Exposure and Health Effects, Proceedings of the $3^{\text {rd }}$ International Conference on Arsenic Exposure and Health Effects, July 12-15, 1998, San Diego, California, Oxford Elsevier Science, p 363-366.

Smedley PL, Kinniburgh DG (2002) A review of the source, behaviour and distribution of arsenic in natural waters. Appl Geochem 17: 517-568.

Smith E, Naidu R, Alston AM (1998). Arsenic in the soil environment: A review. Adv Agron 50:149-195.

US EPA (1995) Integrated risk information system - inorganic arsenic. http://cfpub.epa.gov/iris/quickview.cfm?substance_nmbr $=0278$

Welch AH, Helsel DR, Focazio MJ, Watkins SA (1999) Arsenic in groundwater supplies of the Unites States. In: Chappell WR, Abernathy CO, Calderon RL (eds) Arsenic Exposure and Health Effects: Proceedings of the $3^{\text {rd }}$ International Conference on Arsenic Exposure and Health Effects, July 12-15, 1998, San Diego, California, Oxford Elsevier Science, p 9-17. 